\title{
KEPUASAN KERJA, KOMITMEN ORGANISASI, ORGANIZATIONAL CITIZENSHIP BEHAVIOUR (OCB) DAN PENGARUHNYA TERHADAP KUALITAS PELAYANAN PUBLIK
}

\author{
Restin Meilina \\ Mochammad Wahyu Widodo \\ Universitas Nusantara PGRI Kediri
}

\begin{abstract}
Abstrak
Penelitian ini bertujuan untuk mengetahui (1) pengaruh kepuasan kerja terhadap OCB, (2) pengaruh komitmen organisasi terhadap OCB, (3) pengaruh kepuasan kerja terhadap kualitas pelayanan publik, (4) pengaruh komitmen organisasi terhadap kualitas pelayanan publik, (5) pengaruh OCB terhadap kualitas pelayanan publik, dan (6) pengaruh tidak langsung kepuasan kerja dan komitmen organisasi terhadap kualitas pelayanan publik melalui OCB. Penelitian dilakukan di 3 (tiga) kantor kecamatan yang ada di kota Kediri. Sampel yang diambil sebanyak 90 responden dengan teknik purposive sampling. Pengumpulan data melalui observasi, wawancara, dan penyebaran kuesioner. Data yang diperoleh dianalisis dengan analisis jalur (path). Hasil penelitian menunjukkan (1) kepuasan kerja berpengaruh signifikan terhadap OCB, (2) komitmen organisasi berpengaruh signifikan terhadap $O C B$, (3) kepuasan kerja berpengaruh signifikan terhadap kualitas pelayanan publik, (4) komitmen organisasi berpengaruh signifikan terhadap kualitas pelayanan publik, (5) OCB berpengaruh signifikan terhadap kualitas pelayanan publik, (6) ada pengaruh tidak langsung kepuasan kerja terhadap kualitas pelayanan publik melalui OCB, sedangkan untuk komitmen organisasi tidak ada pengaruh tidak langsung terhadap kualitas pelayanan publik melalui $O C B$.

Kata Kunci: kepuasan kerja, komitmen organisasi, OCB, organizational citizenship behaviour, kualitas pelayanan publik
\end{abstract}

\section{ABSTRACT}

Service employees as the vanguard that plays an important role in determining the quality or not of public services. Efforts to provide quality public services can not ignore the factors of employee job satisfaction, organizational commitment employees, and organizational citizenship behavior (OCB) employees. This study aims to determine (1) the effect of job satisfaction on $O C B$, (2) influence of organizational commitment to $O C B$, (3) influence of job satisfaction on public service quality, (4) influence of organizational commitment to public service quality, (5) influence of $O C B$ On the quality of public services, and (6) the indirect influence of job satisfaction and organizational commitment to the quality of public services through OCB. The study was conducted in 3 (three) sub-district offices in Kediri. Samples taken as many as 90 respondents with purposive sampling technique. Data collection through observation, interviews, and questionnaire dissemination. The data obtained were analyzed by path analysis. The result of the research shows that (1) job satisfaction has significant effect on $O C B$, (2) organizational commitment has significant effect to OCB, (3) job satisfaction has significant effect on public service quality, (4) organizational commitment has significant effect on public service quality, $O C B$ has a significant effect on the quality of public services, (6) there is indirect influence of job satisfaction on the quality of public service through OCB, while for organizational commitment there is no indirect influence to the quality of public service through $O C B$.

Keywords: job satisfaction, organizational commitment, $O C B$, organizational citizenship behavior, quality of public services

\section{PENDAHULUAN}

Undang-Undang Republik Indonesia Nomor 5 Tahun 2014 Tentang Aparatur Sipil Negara menyebutkan pada pasal 11 ayat 2 bahwa Aparatur Sipil Negara (ASN) bertugas memberikan pelayanan publik yang profesional dan berkualitas. Untuk itu, semua instansi pemerintah khususnya yang memberikan pelayanan kepada masyarakat wajib mengupayakan kualitas pelayanan publik, tidak terkecuali di kota Kediri. Terlebih lagi, sejak pertengahan 2016 kota Kediri berkomitmen menjadi kota pelayanan dengan meluncurkan brand kota yang baru yaitu "Harmoni Kediri The Service City".

Pelayanan yang berkualitas tidak bisa otomatis selalu diberikan oleh pegawai pelayanan. Banyak faktor yang dapat mempengaruhinya. Memahami faktor-faktor yang dapat mempengaruhi kualitas pelayanan publik penting agar dapat 
meningkatkan dan mengoptimalkan kualitas pelayanan publik yang diberikan.

Kualitas pelayanan adalah persepsi penerima layanan atas keunggulan suatu pelayanan (Parasuraman, dalam Meilina 2017). Kualitas pelayanan dapat diukur dengan melihat tingkat kesenjangan antara harapan atau keinginan konsumen dengan persepsi mereka atas kinerja produk atau organisasi (Bebko dalam Rudyanto, 2012). Pelayanan publik merupakan fungsi dari aparatur sipil negara (ASN) sebagai pelayan masyarakat (Meilina, 2017). Kualitas pelayanan publik adalah sejauh mana pemerintah mampu memberikan pelayanan sebaik-baiknya bagi masyarakat sekaligus menunjukkan sejauhmana pula negara telah menjalankan perannya sesuai tujuan pendiriannya (Arisman, 2013). Untuk mengukur kualitas pelayanan publik, dasar yang digunakan adalah standar pelayanan publik menurut Keputusan Menteri pendayagunaan Aparatur Negara No. 63 Tahun 2003. Standar tersebut menjadi ukuran dalam penyelenggaraan pelayanan publik yang wajib ditaati oleh pemberi pelayanan. Standar tersebut meliputi:

1. Prosedur pelayanan, berupa aturan baku yang harus diketahui secara jelas bagi pemberi dan penerima layanan.

2. Waktu penyelesaian, ditetapkan sejak pengajuan permohonan sampai penyelesaian pelayanan

3. Biaya pelayanan, ditetapkan dalam proses1. pemberian layanan termasuk rinciannya dengan memperhatikan tingkat kemampuan daya beli masyarakat, harga yang berlaku atas barang dan jasa, 2 . serta ditetapkan oleh pejabat yang berwenang dengan mengacu peraturan perundang-undangan

4. Produk pelayanan, hasil yang akan diterima oleh3. penerima layanan sesuai ketentuan yang telah ditetapkan

5. Sarana dan prasarana, fasilitas yang secara memadai perlu disediakan oleh penyelenggara pelayanan publik

6. Kompetensi petugas pemberi pelayanan, harus ditetapkan secara tepat berdasarkan pengetahuan, keahlian, ketrampilan, sikap, dan perilaku yang dibutuhkan.

Salah satu faktor yang mempengaruhi kualitas pelayanan publik dari pegawai adalah Organizational Citizenship Behaviour (OCB). Hal ini dibuktikan hasil penelitian dari Badruzaman (2012), Rudyanto (2012), dan Surachmad (2010) yang menyatakan bahwa OCB berpengaruh terhadap kualitas pelayanan.

$O C B$ atau perilaku kewarganegaraan organisasi adalah kontribusi pegawai melebihi tuntutan peran di tempat kerja dan reward perolehan kinerja. OCB melibatkan beberapa perilaku menolong orang lain, menjadi volunteer untuk tugas-tugas ekstra, patuh terhadap aturanaturan, dan prosedur-prosedur di tempat kerja. Selain itu, OCB bisa melampaui indikator kinerja yang dibutuhkan oleh sebuah organisasi dalam deskripsi pekerjaan formal, OCB diharapkan dapat mempertahankan dan mempromosikan organisasi (Meilina,2016). Beberapa penelitian menunjukkan bahwa perilaku yang didasarkan pada OCB yang tinggi akan meningkatkan kuantitas dan kualitas produktivitas pegawai (wirawan, 2013), sehingga mendukung peningkatan kinerja individu, organisasi, dan perkembangan organisasi ke arah yang lebih baik (Ahdiyana, 2009).

OCB merupakan perilaku sukarela pegawai yang bersedia melakukan tugas atau pekerjaan diluar tanggung jawab atas kewajibannya demi kemajuan atau keuntungan organisasinya (Garay dalam Meilina, 2016), sebagai wujud dari kepuasan, tanpa diperintahkan, dan tidak berhubungan dengan reward atau kompensasi (Darto, 2014). Beberapa contoh OCB adalah perilaku membantu teman sekerja yang mengalami kesulitan dalam pekerjaan, mencegah terjadinya ancaman bahaya yang dapat merugikan organisasi, perilaku menjaga kebersihan dan kenyamanan tempat kerja, atau menyelesaikan pekerjaan melebihi standar yang dituntut.

Menurut Organ et al (dalam Meilina, 2016) dimensi OCB adalah sebagai berikut:

Altruism : Perilaku membantu pegawai lain tanpa ada paksaan pada tugas-tugas yang berkaitan erat dengan operasi-operasi organisasi.

Civic Virtue: Menunjukkan partisipasi sukarela dan dukungan terhadap fungsi-fungsi organisasi baik secara profesional maupun sosial alamiah

Conscientiousness Berisi tentang kinerja dan prasyarat peran yang melebihi standar minimum.

4. Courtesy: Perilaku meringankan problem-problem yang berkaitan dengan pekerjaan yang dihadapi orang lain

5. Sportmanship: Berisi tentang pantangan-pantangan membuat isu-isu yang merusak meskipun merasa jengkel

Penelitian Meilina (2016) membuktikan ada 2 (dua) faktor internal penting yang mempengaruhi OCB yaitu kepuasan kerja dan komitmen organisasi. Penelitian lain dari Puspitawati (2013) membuktikan bahwa kepuasan kerja dan komitmen organisasi berpengaruh signifikan terhadap kualitas pelayanan. Hal ini menunjukkan bahwa kepuasan kerja dan komitmen organisasi berpengaruh penting bagi OCB dan bagi kualitas pelayanan.

Dalam suatu organisasi keadaan yang sesuai harapan pegawai, akan menimbulkan suasana yang dapat menyenangkan pegawai, sehingga 
pegawai akan merasa puas dan nyaman untuk bekerja. Seseorang yang bergabung dengan suatu organisasi tentunya membawa keinginan-keinginan, kebutuhan, dan pengalaman masa lalu yang membentuk harapan kerja baginya, dan bersamasama dengan organisasinya berusaha mencapai tujuan bersama. Untuk dapat bekerjasama dan berprestasi dengan baik, seorang pegawai harus mempunyai komitmen yang tinggi pada1 organisasinya. Komitmen organisasi dapat tumbuh dengan terpenuhinya kepuasan kerja. Tingkat kepuasan kerja banyak menunjukkan kesesuaiannya dengan harapan kerja (Tranggono dan Kartika, 2008).

Kepuasan kerja merupakan hasil penilaian terhadap suatu pekerjaan berdasarkan pengalaman kerja yang ditunjukkan dengan ungkapan emosional2. bersifat positif atau menyenangkan (Meilina,2016). Kepuasan kerja terdiri dari dua unsur yaitu kognitif (penilaian dari pekerjaan seseorang) dan afektif (keadaan emosi). indikator kepuasan kerja menurut (Gardner, 2008) adalah:

1. Kepuasan Terhadap Pekerjaan Itu Sendiri Pekerjaan yang dapat menimbulkan kepuasan adalah pekerjaan yang dapat dikerjakan dengan baik dan pada hakikatnya merupakan pekerjaan yang menarik, menantang, dan tidak membosankan.

2. Kepuasan Terhadap Gaji

Gaji merupakan faktor utama dalam kepuasan pegawai. Uang tidak hanya membantu pegawai memenuhi kebutuhan dasar mereka, tetapi instrumen dalam memberikan kepuasan pemenuhan kebutuhan dan keinginan pegawai. Sistem penggajian yang adil dapat membuat pegawai senang dalam melakukan pekerjaan.

3. Kepuasan Terhadap Supervisi

Supervisi mempunyai peran yang sangat penting didalam manajemen. Supervisi berhubungan dengan pegawai dan mempengaruhi pegawai dalam melakukan pekerjaannya.

4. Kepuasan Terhadap Rekan Kerja

Rekan kerja berpengaruh terhadap kepuasan kerja pegawai . Rekan kerja yang baik, ramah, dan mendukung akan menghasilkan kepuasan kerja yang tinggi dalam melakukan pekerjaannya

Kepuasan kerja yang didapatkan oleh pegawai akan meningkatkan komitmen organisasi. Seorang pegawai yang semula kurang memiliki komitmen berorganisasi, namun setelah bekerja ternyata mendapat kepuasan kerja, akan memupuk berkembangnya komitmen berorganisasi. Namun juga sebaliknya, jika organisasi kerja dalam perusahaan tersebut kurang menunjang, misalnya fasilitas kurang, hubungan kerja kurang harmonis, jaminan sosial, dan keamanan kurang maka komitmen organisasi kerja makin luntur.
Komitmen organisasi menunjukkan kekuatan dari keterlibatan dan kesetiaan pegawai terhadap organisasi, yang menjadi suatu ikatan psikologis pegawai pada organisasi (Meilina,2016). Pegawai yang tinggi komitmen organisasinya akan menghasilkan kinerja yang tinggi pula (Sopiah,2008). Indikator komitmen organisasi menurut Bushra et al, (2011) terdiri dari:

Continuance commitment : keterikatan pegawai secara psikologis pada organisasi karena biaya yang dia tanggung jika keluar organisasi. Pegawai mengalkulasi manfaat serta pengorbanan atas keterlibatan dalam suatu organisasi dan akan cenderung memiliki daya tahan atau komitmen yang tinggi dalam keanggotaan jika pengorbanan akibat keluar organisasi semakin tinggi.

Normative Commitment : keterkaitan pegawai secara psikologis dengan organisasi karena kewajiban moral untuk memelihara hubungan dengan organisasi. Pegawai tetap berada dan memberikan sumbangan pada organisasi, baik materi maupun non materi karena adanya kewajiban moral.

3. Affective commitment : tingkat keterkaitan secara psikologis dengan organisasi berdasarkan perasaaan pada organisasi. Komitmen ini muncul dan berkembang oleh dorongan adanya kenyamanan, keamanan, dan manfaat lain yang dirasakan dalam organisasi. Semakin nyaman dan tinggi manfaat yang dirasakan oleh pegawai, semakin tinggi komitmennya pada organisasi.

Kota Kediri, melalui new brand "Harmoni Kediri The Service City" yang dilaunching pada pertengahan tahun 2016, berusaha menunjukkan komitmennya sebagai kota pelayanan. Beragam upaya dilakukan oleh pemerintah kota Kediri untuk memperbaiki pelayanan publiknya, mulai dari renovasi ruang pelayanan supaya nyaman, penyederhanaan layanan perizinan dengan kebijakan pemangkasan 97 izin, pelayanan keliling, hingga pelatihan pelayanan publik.

Penelitian ini bertujuan untuk mengetahui kota pengaruh kepuasan kerja, komitmen organisasi, dan OCB terhadap kualitas pelayanan publik di kota Kediri.Wilayah Kediri dibagi menjadi 3 kecamatan yaitu kecamatan Mojoroto, kecamatan Kota, dan kecamatan Pesantren. Penelitian ini mengambil objek 3 (tiga) kecamatan tersebut sebagai representasi kantor pelayanan publik kota Kediri yang memberikan pelayanan kepada masyarakat kota Kediri untuk masalah kependudukan (KTP, KK, Akta Kelahiran, Surat Pindah,dll), masalah perijinan (IMB, ijin keramaian, dll), dan masalah pembuatan akta tanah.

Berdasarkan uraian diatas, dapat dirumuskan masalah penelitian ini sebagai berikut: 
1. Apakah kepuasan kerja berpengaruh terhadap OCB di kantor pelayanan publik kota Kediri?

2. Apakah komitmen organisasi berpengaruh terhadap OCB di kantor pelayanan publik kota Kediri?

3. Apakah kepuasan kerja berpengaruh terhadap kualitas pelayanan publik di kantor pelayanan publik kota Kediri?

4. Apakah komitmen organisasi berpengaruh terhadap kualitas pelayanan publik di kantor pelayanan publik kota Kediri?

5. Apakah OCB berpengaruh terhadap kualitas pelayanan publik di kantor pelayanan publik kota Kediri?

6. Apakah kepuasan kerja dan komitmen organisasi secara tidak langsung berpengaruh terhadap kualitas pelayanan publik di kantor pelayanan publik kota Kediri melalui OCB?

Pegawai yang memiliki kepuasan kerja sehingga komitmennya kuat untuk keberhasilan organisasi, diharapkan akan memiliki OCB yang1. dapat meningkatkan kinerjanya dalam memberikan pelayanan publik yang berkualitas.

\section{METODE PENELITIAN}

\section{A. Rancangan Penelitian}

Penelitian ini menggunakan pendekatan kuantitatif karena data yang diperoleh berupa angkaangka dari skor kuesioner, jenis penelitiannya kausalitas karena mencari hubungan yang sifatnya pengaruh atau sebab akibat. Rancangan penelitian ini adalah sebagai berikut:

Gambar 1 : Rancangan Penelitian

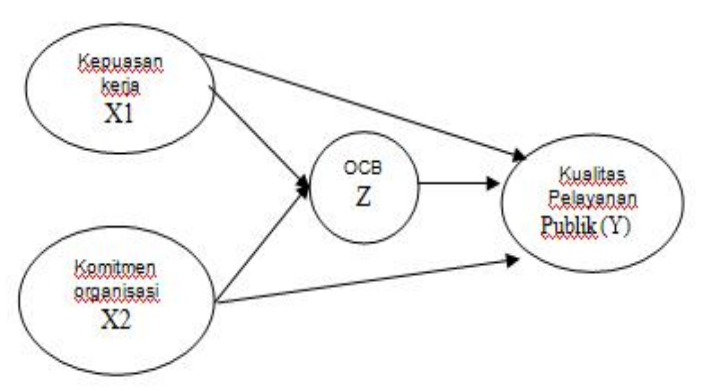

B. Populasi dan Sampel

Populasi dalam penelitian ini dibagi menjadi dua yaitu pegawai bagian pelayanan dan masyarakat yang mendapatkan pelayanan di kantok. pelayanan publik kota Kediri. Sampel diambil dengan teknik purposive sampling karena menggunakan pertimbangan tertentu (Sugiyono, 2015:85). Sampel yang dipilih adalah pegawai kantor kecamatan karena kantor kecamatan tersebar mewakili setiap wilayah kota Kediri mulai wilayah barat, tengah, dan timur serta merupakan jalur pelayanan sebelum ke Dispendukcapil, DPM, dan urusan lain selain kependudukan dan perijinan (waris, akta tanah, dll). Untuk pegawai pelayanan masing-masing kantor kecamatan terdiri dari 15 orang sehingga total 45 responden, dan sampel dari masyarakat yang mendapatkan pelayanan diambil 45 responden dengan pertimbangan masyarakat tersebut yang telah menerima pelayanan dari responden pegawai yang di teliti sehingga lebih akurat dalam memberikan penilaian tentang kualitas pelayanan pegawai.

\section{Analisis Data}

Data dikumpulkan melalui kuesioner berisi pernyataan-pernyataan yang sudah disediakan pilihan jawabannya dan diukur dengan skala Likert 1 sampai 5. Data yang terkumpul di analisis dengan analisis jalur (Path Analysis) dengan tahap-tahap sebagai berikut:

\section{Uji Asumsi Klasik}

Pengujian asumsi klasik yang bertujuan untuk menentukan ketepatan model. Uji asumsi klasik yang akan digunakan dalam penelitian ini meliputi:

a. Linearitas Hubungan Antar Variabel

Linearitas Hubungan antar variabel artinya adanya perubahan satu variabel (variabel bebas) akan terus diikuti dengan perubahan variabel yang lain (variabel terikat). Untuk mengetahui linieritas hubungan kausal, dapat diketahui dengan uji $\mathrm{F}$ melalui Curve Estimation. Apabila nilai $\mathrm{F}$ hitung dari setiap hubungan kausal dua variabel lebih besar dari $\mathrm{F}$ tabel, maka dapat dikatakan hubungan kausal tersebut adalah linier

b. Pola Hubungan Antar Variabel Adalah Rekursif

Model rekursif mempunyai arti sistem aliran kausalnya hanya ke satu arah saja. Pada model penelitian ini model yang digunakan adalah model rekursif dengan kata lain tidak ada variabel yang mempunyai pengaruh bolak-balik (hubungan kausalnya searah), yaitu Kepuasan Kerja (X1) dan Komitmen Organisasi (X2) mempunyai hubungan kausal dengan OCB (Z), demikian juga dengan Kepuasan Kerja (X1), Komitmen Organisasi (X2) dan OCB (Z) juga mempunyai hubungan kausal dengan Kualitas Pelayanan publik (Y). Dengan demikian asumsi mengenai model rekursif pada model penelitian ini terpenuhi.

Tingkat Pengukuran Semua Variabel Minimal Interval

Analisis jalur (path analysis) menghendaki nilai variabel yang digunakan dalam pemodelan minimal mempunyai skala data interval. Skala data mempunyai urutan yaitu nominal-ordinal-interval- 
ratio, dimana nominal adalah skala data terendah dan ratio adalah skala data tertinggi.

Dalam penelitian ini skala data yang digunakan adalah skala likert di mana skala data ini adalah skala tipe interval, sehingga analisis path bisa digunakan untuk data penelitian ini.

\section{Analisis Jalur (Path Analysis)}

Analisis jalur untuk mengetahui pengaruh variabel eksogen (kepuasan dan komitmen Organisasi) terhadap variabel endogen (OCB dan kualitas pelayanan publik), serta untuk mengetahui pengaruh langsung dan tidak langsung variabel eksogen terhadap variabel endogen.

\section{Uji Hipotesis}

Uji hipotesis digunakan untuk menjawab rumusan masalah yang bersifat kuantitatif. Cara yang digunakan antara lain:

a. Uji signifikansi Parameter individual (Uji statistik t). Dilakukan dengan membandingkan nilai t hitung dengan $t$ tabel atau signifikansi level 0,05 ( $\alpha$ $=5 \%$ ). Jika nilai $\mathrm{t}$ hitung $<\mathrm{t}$ tabel dan signifikan > 0,05 berarti tidak ada pengaruh secara parsial, Jika nilai $\mathrm{t}$ hitung $>\mathrm{t}$ tabel dan signifikan $<0,05$ berarti ada pengaruh secara parsial.

b. Koefisien determinasi $\left(\mathrm{R}^{2}\right)$ untuk mengukur kemampuan model dalam menerangkan variabel-

Hasil uji linieritas dapat dilihat pada pada Tabel di bawah ini.

Tabel 1 : Hasil Uji Linieritas Tiap Lintasan

\begin{tabular}{|c|c|c|c|c|c|}
\hline \multicolumn{3}{|c|}{ Keterorongan } & \multirow{2}{*}{$\begin{array}{l}\text { F hirung } \\
31.159\end{array}$} & \multirow{2}{*}{$\begin{array}{c}1+\operatorname{tab} c 1 \\
(\mathrm{dfl}=1, \mathrm{df} f=13, \alpha=5 \% \%) \\
1,057\end{array}$} & \multirow{2}{*}{$\frac{\text { Keterangez }}{\text { Linier }}$} \\
\hline $\begin{array}{c}\text { Kerciasan } \\
\text { Kenja } \\
\text { (X1) }\end{array}$ & $\rightarrow$ & $\operatorname{OCB}(\mathcal{Z})$ & & & \\
\hline $\begin{array}{l}\text { Komitmen } \\
\text { Orys:issasi } \\
(\mathrm{X2})\end{array}$ & $\rightarrow$ & $\mathrm{OCB}(\mathrm{Z})$ & 23,230 & 4.057 & Liviet \\
\hline $\begin{array}{c}\text { KErkuggan } \\
\text { Kena } \\
\text { (X1) }\end{array}$ & $>$ & $\begin{array}{l}\text { Kualitas } \\
\text { l'exyanan } \\
\text { Publiz:(Y) } \\
\end{array}$ & $3,3 / 2$ & 4,067 & 1 .mier \\
\hline $\begin{array}{l}\text { Komptrinen } \\
\text { Ongixzasi } \\
(X))\end{array}$ & $\rightarrow$ & \begin{tabular}{l|} 
Kr:alitas \\
Pe:ay anan \\
hlahlhs $(V)$ \\
\end{tabular} & 59,270 & 2,057 & Linier \\
\hline $\operatorname{ocs}(z)$ & $\rightarrow$ & \begin{tabular}{l|} 
Kualitas \\
Peiay ardart \\
Publik $(Y)$ \\
\end{tabular} & 48,626 & 1,057 & Luxiet \\
\hline
\end{tabular}

Berdasarkan Tabel di atas terlihat bahwa semua lintasan mempunyai hubungan linier yaitu lintasan pengaruh Kepuasan Kerja (X1), Komitmen Organisasi (X2) terhadap OCB (Z), serta lintasan pengaruh Kepuasan Kerja (X1), Komitmen Organisasi (X2) dan OCB (Z)

b. Pola Hubungan Antar Variabel Adalah Rekursif

Asumsi mengenai model rekursif pada model penelitian ini terpenuhi karena pada model penelitian ini tidak ada variabel yang mempunyai pengaruh bolak-balik (hubungan kausalnya searah).

2. Analisis Jalur (Path Analysis)

a. Hubungan searah Kepuasan Kerja dan Komitmen Organisasi Terhadap OCB variabel dependen. Nilai koefisien determinasi adalah antara 0 dan 1 . Nilai yang mendekati 1 berarti variabel-variabel independen memberikan hampir semua informasi yang dibutuhkan untuk memprediksi variasi variabel dependen.

Terdapat 6 hipotesis yang akan diuji pada penelitian ini, 5 hipotesis mengenai pengaruh langsung dan 1 hipotesis mengenai pengaruh tidak langsung yaitu:

H1: ada pengaruh kepuasan kerja terhadap OCB

$\mathrm{H} 2$ : ada pengaruh komitmen organisasi terhadap OCB

H3: ada pengaruh kepuasan kerja terhadap kualitas pelayanan publik

H4: ada pengaruh komitmen organisasi terhadap kualitas pelayanan publik

H5: ada pengaruh OCB terhadap kualitas pelayanan publik

H6: ada pengaruh tidak langsung kepuasan kerja dan komitmen organisasi terhadap kualitas pelayanan publik melalui OCB

\section{HASIL DAN PEMBAHASAN}

\section{Uji Asumsi Klasik}

a. Linearitas Hubungan Antar Variabel

\begin{tabular}{|c|c|c|c|c|c|}
\hline \multicolumn{3}{|c|}{ Keteroran } & \multirow{2}{*}{$\begin{array}{l}\text { F hijing } \\
31,159\end{array}$} & \multirow{2}{*}{$\begin{array}{c}1 \cdot \operatorname{tab} d \\
(\mathrm{df} 1=1, \mathrm{df} 2=13 . \alpha=5 \% \%) \\
1.057\end{array}$} & \multirow{2}{*}{$\frac{\text { Keterangay }}{\text { Linjer }}$} \\
\hline $\begin{array}{c}\text { Kerciasang } \\
\text { Kenja } \\
\text { (xi) }\end{array}$ & $\rightarrow$ & $O C B(Z)$ & & & \\
\hline $\begin{array}{l}\text { Komitmen } \\
\text { Orya:1sasi } \\
\text { (X2) }\end{array}$ & $\rightarrow$ & $O C B(Z)$ & 23,230 & 4.057 & Liviet \\
\hline $\begin{array}{c}\text { Kertuagan } \\
\text { Kena } \\
\text { (X1) }\end{array}$ & $>$ & $\begin{array}{l}\text { Kualitas } \\
\text { l'e ay anาan } \\
\text { Publik (Y) }\end{array}$ & 32,3, & 4,067 & 1 mier \\
\hline $\begin{array}{l}\text { Komvitunen } \\
\text { Ongineazi } \\
(K))\end{array}$ & $\rightarrow$ & 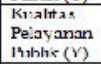 & 55,270 & 4.057 & Linier \\
\hline $\operatorname{OCs}(z)$ & $\rightarrow$ & $\begin{array}{l}\text { Kualitas } \\
\text { Pelay ardart } \\
\text { Publik (Y) }\end{array}$ & 48,626 & 1,057 & Liviet \\
\hline
\end{tabular}

Sumber : Output Uji Linieritas

terhadap Kualitas Pelayanan publik (Y) juga mempunyai hubungan linier. Asumsi linieritas berpengaruh terhadap kesahihan estimasi parameter model yang dihasilkan, sehingga semakin baik pula model yang dihasilkan. c. Tingkat Pengukuran Semua Variabel
Minimal Interval

Dalam penelitian ini skala data yang digunakan adalah skala likert di mana skala data ini adalah skala tipe interval, sehingga analisis path bisa digunakan untuk data penelitian ini.

Berikut hasil regresi I Kepuasan Kerja dan Komitmen Organisasi Terhadap OCB: 
Hasil Regresi Kepuasan Kerja dan Komitmen Organisasi Terhadap OCB

\begin{tabular}{|c|c|c|c|}
\hline Prazta & 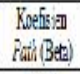 & thingers & $\begin{array}{c}\because a b d \\
(d=42,0 Q=0,02)\end{array}$ \\
\hline Requegnigig (XI) & 0,464 & 3,309 & $201:$ \\
\hline Bomimen Oregeniszi $(X)$ & 0.332 & 25.11 & 2ill: \\
\hline 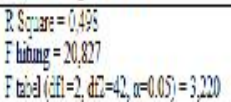 & & & \\
\hline
\end{tabular}

Cofficiand

\begin{tabular}{|c|c|c|c|c|c|c|}
\hline \multirow{2}{*}{\multicolumn{2}{|c|}{ Ylods }} & \multicolumn{2}{|c|}{ Ustededrined Coefficien } & $\begin{array}{l}\text { Salcadirad } \\
\text { Coeficinens }\end{array}$ & \multirow[b]{2}{*}{ t } & \multirow[b]{2}{*}{ Sig. } \\
\hline & & 3 & Ste Enou & Bea & & \\
\hline & (Cosint & 00,615 & 10,999 & & 1,884 & 068 \\
\hline & Eer.:3!neria & $1,35 \hat{3}$ &, 396 & ,4:4 & 3,500 &, 001 \\
\hline & Eomiten CEnis: & $1,311$. & .22 & $3:$ & 2,511 & 016 \\
\hline
\end{tabular}

a. Deperiatt amiz 008

Sumber : Output Regresi I

Berdasarkan tabel di atas didapatkan persamaan sebagai berikut : $Z=0,464 \mathrm{X} 1+0,332 \mathrm{X} 2$

b. Hubungan searah Z Terhadap Y

Berikut hasil regresi II Kepuasan Kerja, Komitmen Organisasi dan OCB Terhadap Kualitas Pelayanan publik:

Berdasarkan tabel di atas didapatkan persamaan sebagai berikut : $\mathrm{Y}=0,233 \mathrm{X} 1+0,427 \mathrm{X} 2+0.324 \mathrm{Z}$

Setelah didapatkan dua model pengaruh di atas, selanjutnya dapat disusun model path/lintasan, dengan pengaruh error yang ditentukan sebagai

Dengan demikian dapat dibuat diagram path sebagai beriku.

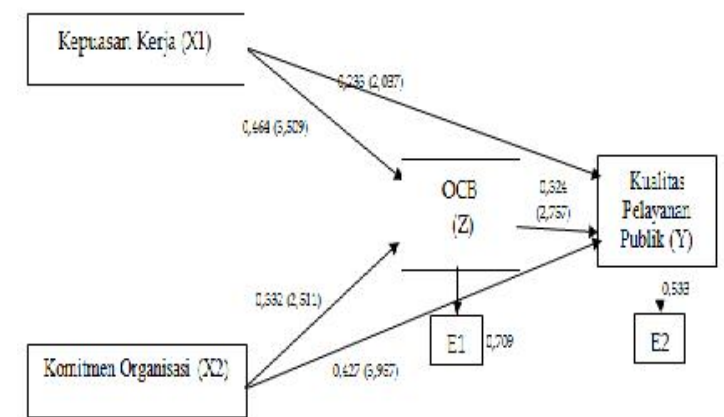

Gambar 2 : Diagram Path dengan Koefisien Path. dan Nilai t hitungnya

Setelah didapatkan model seperti yang telah disajikan pada Gambar di atas, selanjutnya akan dihitung koefisien determinasi total. Koefisien determinasi total adalah total keragaman yang dapat
Tabel 3: Hasil Regresi Kepuasan Kerja, Komitmen Organisasi dan OCB Terhadap Kualitas Pelayanan publik

\begin{tabular}{|c|c|c|c|}
\hline Pararet:ti & 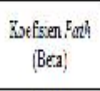 & thtreg & 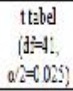 \\
\hline 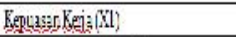 & 0,233 & 2,037 & 20020 \\
\hline Kcrnibnen (-granisai (X2) & 0,27 & 3557 & 2002 \\
\hline$X C B(Z)$ & 0,24 & 2,753 & 200 \\
\hline 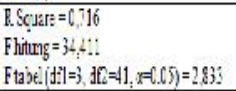 & & & \\
\hline
\end{tabular}

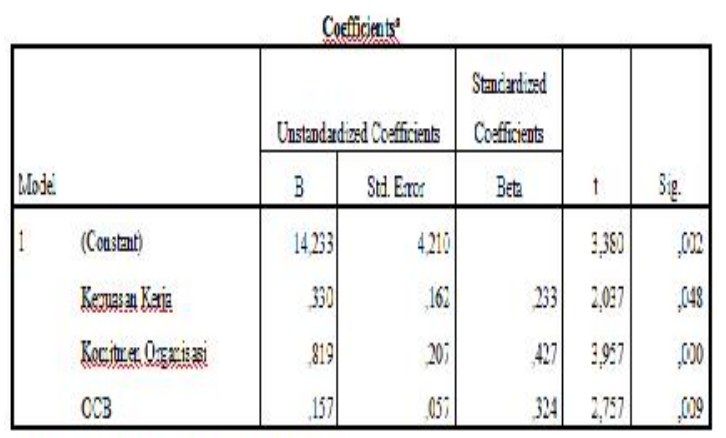

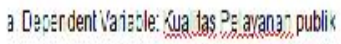

Sumber : Output Regresi II

berikut: Pei $=\sqrt{1-R i^{2}}=(1-\mathrm{Ri})^{0.5}$

\section{Dimana:}

Pe1 $=(1-0,498)^{0.5}=0,709$

$\mathrm{Pe} 2=(1-0,716)^{0.5}=0,533$

dijelaskan oleh model. Total keragaman tersebut dapat dihitung dengan formula sebagai berikut:

$$
\begin{aligned}
\mathrm{R} 2 \mathrm{~m} & =1-(\mathrm{Pe} 12 \times \mathrm{Pe} 22) \\
& =1-(0,7092 \times 0,5332)=0,857=85,7 \%
\end{aligned}
$$

Didapatkan koefisien determinasi total sebesar $85,7 \%$, artinya keragaman data yang dapat dijelaskan oleh model dalam penelitian ini adalah sebesar $85,7 \%$ atau dengan kata lain informasi yang terkandung dalam data, $85,7 \%$ dapat dijelaskan oleh model tersebut, sedangkan sisanya sebesar $14,3 \%$ dijelaskan oleh variabel lain (yang belum terdapat dalam model) dan error.

\section{Uji Hipotesis}

Terdapat 6 hipotesis yang akan diuji pada penelitian ini, yaitu 5 hipotesis mengenai pengaruh langsung dan 1 hipotesis mengenai pengaruh tidak langsung. Berikut akan dibahas pengujian hipotesis pada pengaruh langsung dan pengaruh tidak langsung. 
Ringkasan pengujian pengaruh langsung tampak pada tabel 4 berikut ini:

Tabel 4: Pengujian pengaruh langsung

\begin{tabular}{|c|c|c|c|c|c|}
\hline Hipotesis & $\begin{array}{c}\text { Lintasan } \\
(\text { Path })\end{array}$ & Sig t & t hitung & $\begin{array}{c}\mathrm{t} \\
\text { tabel }\end{array}$ & Keterangan \\
\hline 1 & $\mathrm{X} 1 \rightarrow \mathrm{Z}$ & 0,001 & 3,509 & 2,018 & Signifikan \\
\hline 2 & $\mathrm{X} 2 \rightarrow \mathrm{Z}$ & 0,016 & 2,511 & 2,018 & Signifikan \\
\hline 3 & $\mathrm{X} 1 \rightarrow \mathrm{Y}$ & 0,048 & 2,037 & 2,020 & Signifikan \\
\hline 4 & $\mathrm{X} 2 \rightarrow \mathrm{Y}$ & 0,000 & 3,957 & 2,020 & Signifikan \\
\hline 5 & $\mathrm{Z} \rightarrow \mathrm{Y}$ & 0,009 & 2,757 & 2,020 & Signifikan \\
\hline
\end{tabular}

Sumber: output regresi I dan II Ringkasan pengujian pengaruh tidak langsung tampak pada tabel 5 berikut ini:

Tabel 5: pengujian pengaruh tidak langsung

\begin{tabular}{|c|c|c|c|}
\hline $\begin{array}{c}\text { Lintasan } \\
(\text { Path })\end{array}$ & $\begin{array}{c}\text { Koefisien } \\
\text { Path }\end{array}$ & $\begin{array}{c}\text { Nilai } \\
\text { Signifikansi } \\
(\text { p-value })\end{array}$ & Keterangan \\
\hline $\mathrm{X} 1 \rightarrow \mathrm{Z} \rightarrow \mathrm{Y}$ & 0,150 & 0,030 & Signifikan \\
\hline $\mathrm{X} 2 \rightarrow \mathrm{Z} \rightarrow \mathrm{Y}$ & 0,108 & 0,063 & Tidak Signifikan \\
\hline
\end{tabular}

Sumber: hasil perhitungan

H1: Pengaruh Kepuasan Kerja (X1) terhadap OCB (Z) mempunyai koefisien regresi baku (beta) sebesar 0,464, artinya semakin tinggi Kepuasan Kerja, maka semakin baik OCB di kantor pelayanan publik kota Kediri. Pengaruh tersebut signifikan karena nilai $t$ hitung koefisien lintasannya (path) lebih besar dari t tabel yaitu 3,509 > 2,018 dan nilai signifikansi t nya $0,001<0.05$. Dengan demikian hipotesis penelitian yang menduga bahwa Kepuasan Kerja mempunyai pengaruh yang signifikan terhadap OCB, terbukti kebenarannya.

H2: Pengaruh Komitmen Organisasi (X2) terhadap OCB (Z) mempunyai koefisien regresi baku (beta) sebesar 0,332, artinya semakin tinggi Komitmen Organisasi, maka semakin baik OCB di kantor pelayanan publik kota Kediri. Pengaruh tersebut signifikan karena nilai t hitung koefisien lintasannya (path) lebih besar dari t tabel yaitu 2,511 > 2,018 dan nilai signifikansi t nya $0,016<0,005$. Dengan demikian hipotesis penelitian yang menduga bahwa Komitmen Organisasi mempunyai pengaruh yang signifikan terhadap OCB, terbukti kebenarannya.

H3: Pengaruh Kepuasan Kerja (X1) terhadap Kualitas Pelayanan publik (Y) mempunyai koefisien regresi baku (beta) sebesar 0,233, artinya semakin tinggi Kepuasan Kerja, maka semakin baik Kualitas Pelayanan publik di kantor pelayanan publik kota Kediri. Pengaruh tersebut signifikan karena nilai $\mathrm{t}$ hitung koefisien lintasannya (path) lebih besar dari t tabel yaitu 2,037> 2,020 dan nilai signifikansi t nya $0,048<0,05$. Dengan demikian hipotesis penelitian yang menduga bahwa Kepuasan Kerja mempunyai pengaruh yang signifikan terhadap Kualitas Pelayanan publik, terbukti kebenarannya.

H4: Pengaruh Komitmen Organisasi (X2) terhadap Kualitas Pelayanan publik (Y) mempunyai koefisien regresi baku (beta) sebesar 0,427 , artinya semakin tinggi Komitmen Organisasi, maka semakin baik Kualitas Pelayanan publik di kantor pelayanan publik kota Kediri. Pengaruh tersebut signifikan karena nilai $t$ hitung koefisien lintasannya (path) lebih besar dari t tabel yaitu $3,957>2,020$ dan nilai signifikansi t nya $0,000<0,05$. Dengan demikian hipotesis penelitian yang menduga bahwa Komitmen Organisasi mempunyai pengaruh yang signifikan terhadap Kualitas Pelayanan publik, terbukti kebenarannya.

H5: Pengaruh OCB (Z) terhadap Kualitas Pelayanan publik (Y) mempunyai koefisien regresi baku (beta) sebesar 0,324, artinya semakin tinggi OCB, maka semakin baik Kualitas Pelayanan publik di kantor pelayanan publik kota Kediri. Pengaruh tersebut signifikan karena nilai $t$ hitung koefisien lintasannya (path) lebih besar dari t tabel yaitu 2,757> 2,020 dan nilai signifikansi t nya $0.0009<$ 0,005. Dengan demikian hipotesis penelitian yang menduga bahwa OCB mempunyai pengaruh yang signifikan terhadap Kualitas Pelayanan publik, terbukti kebenarannya.

\section{H6: Pengaruh Tidak Langsung}

Dalam model penelitian ini, akan dihitung pengaruh tidak langsung Kepuasan Kerja dan Komitmen Organisasi terhadap Kualitas Pelayanan publik melalui OCB. Perhitungan dilakukan dengan media online "interactive mediation test" di situs: quantpsy.org/sobel/sobel.htm. Berikut adalah besarnya pengaruh tidak langsung :

Besar pengaruh tidak langsung $\mathrm{X} 1$ terhadap $\mathrm{Y}$ melalui $\mathrm{Z}=$ $0,464 \times 0,324=0,150$

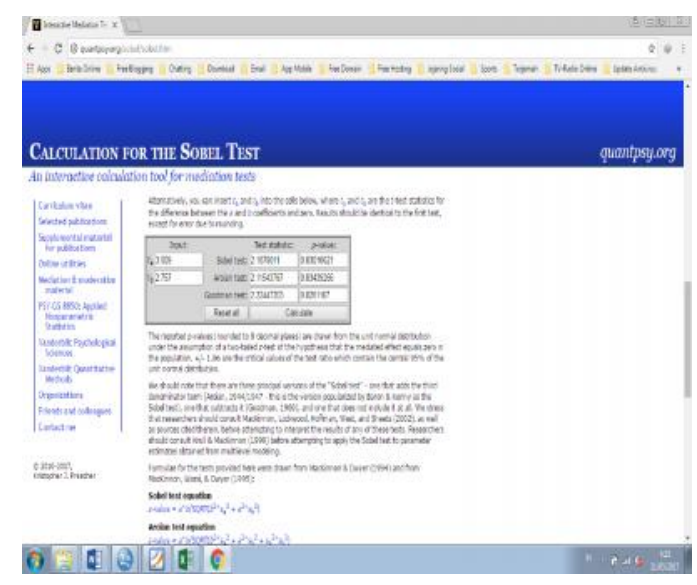


Gambar 3: perhitungan pengaruh tidak langsung Kepuasan Kerja terhadap Kualitas Pelayanan publik melalui OCB

Hasil t-statistics dari pengaruh tidak langsung Kepuasan Kerja terhadap Kualitas Pelayanan publik melalui OCB sebagai variabel mediasi adalah sebesar 2,168 dengan nilßi signifikansi 0,030 . Nilai signifikansi lebih kecil dari 0,05 , sehingga hipotesis penelitian yang menduga bahwa Kepuasan Kerja mempunyai pengaruhtidak langsung yang signifikan terhadap Kualitas Pelayanan publik di kantor pelayanan publik kota Kediri melalui OCB, terbukti kebenarannya.

Besar Pengaruh tidak langsung $\mathrm{X} 2$ terhadap $\mathrm{Y}$ melalui $\mathrm{Z}=0,332 \times 0,324=0,108$

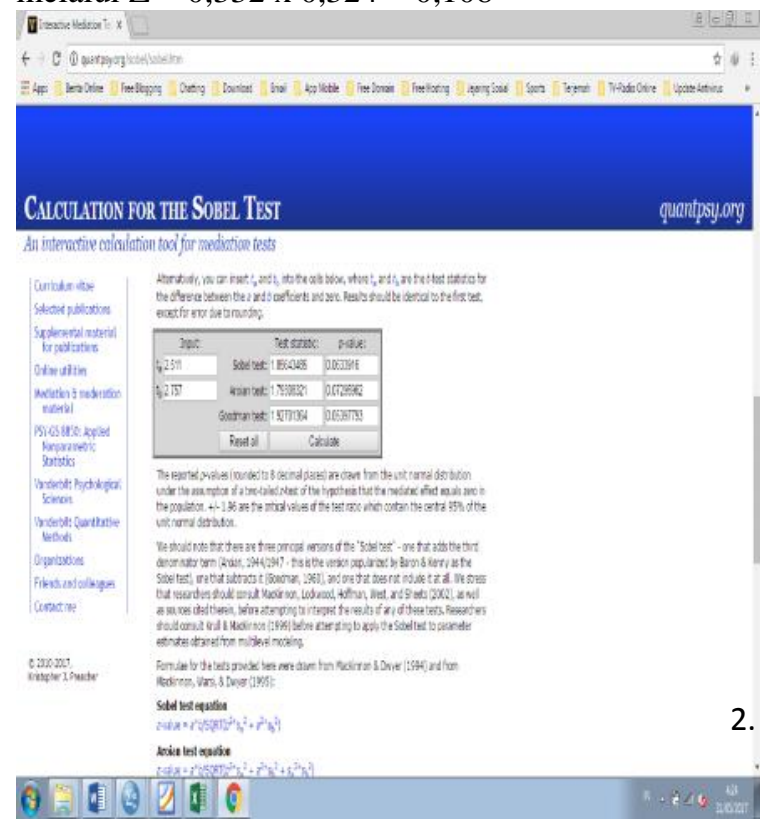

Gambar 4: Perhitungan pengaruh tidak langsung Komitmen Organisasi terhadap Kualitas Pelayanan publik melalui OCB

Hasil t-statistics dari pengaruh tidak langsung Komitmen Organisasi terhadap Kualitæs Pelayanan publik melalui OCB sebagai variabel mediasi adalah sebesar 1,856 dengan nilai signifikansi 0,063. Pengaruh tidak langsung komitmen organisasi terhadap Kualitas Pelayanan publik melalui OCB memiliki nilai signifikansi yang lebih besar dari 0,05, dengan demikian hipotesis penelitian yang menduga bahwa Komitmen Organisasi mempunyai pengaruh tidak langsung yang signifikan terhadap Kualitas Pelayanan publik melalui $\mathrm{OCB}$, tidak terbukti kebenarannya.

\section{SIMPULAN}

Berdasarkan pembahasan di atas, dapat ditarik simpulan sebagai berikut:
Kepuasan kerja pegawai berpengaruh signifikan terhadap OCB di kantor pelayanan publik kota Kediri

Komitmen organisasi pegawai berpengaruh signifikan terhadap OCB di kantor pelayanan publik kota Kediri

Kepuasan kerja pegawai berpengaruh signifikan terhadap kualitas pelayanan publik di kantor pelayanan publik kota Kediri

4. Komitmen organisasi pegawai berpengaruh signifikan terhadap kualitas pelayanan publik di kantor pelayanan publik kota Kediri

5. OCB berpengaruh signifikan terhadap kualitas pelayanan publik di kantor pelayanan publik kota Kediri

6. Kepuasan kerja pegawai berpengaruh signifikan secara tidak langsung terhadap kualitas pelayanan publik di kota kediri melalui OCB, sedangkan komitmen organisasi pegawai tidak berpengaruh signifikan secara tidak langsung melalui OCB terhadap kualitas pelayanan publik di kantor pelayanan publik kota Kediri

\section{SARAN}

1. Kepuasan kerja berpengaruh positif signifikan bagi kualitas pelayanan publik baik secara langsung maupun secara tidak langsung melalui OCB. Sehingga untuk meningkatkan kualitas pelayanan publik pembuat kebijakan harus benarbenar memperhatikan faktor kepuasan kerja pegawainya baik kepuasan terhadap pekerjaan, gaji, supervisi, dan rekan kerja.

2. Komitmen Organisasi berpengaruh positif signifikan bagi kualitas pelayanan publik secara langsung. Untuk meningkatkan kualitas pelayanan publik, pegawai harus memiliki komitmen yang tinggi pada pekerjaan serta organisasinya. Komitmen yang tinggi dapat dipupuk dengan memenuhi kepuasan kerja pegawai tersebut.

OCB berpengaruh positif signifikan bagi kualitas pelayanan publik. Untuk meningkatkan kualitas pelayanan publik, pegawai harus memiliki OCB yang tinggi. Meningkatkan OCB dapat dilakukan dengan memenuhi kepuasan kerja pegawai dan meningkatkan komitmen organisasi pegawai tersebut. Hasil penelitian membuktikan kepuasan kerja dan komitmen organisasi pegawai berpengaruh terhadap OCB.

Untuk penelitian selanjutnya disarankan mengganti objek penelitian pada kantor pelayanan publik yang lain di kota Kediri seperti Dinas Penanaman Modal (DPM), Dinas kependudukan dan pencatatan sipil (Dispendukcapil), dan yang lainnya agar lebih memperkuat hasil penelitian ini. Atau dapat juga menambah variabel dan metode penelitiannya 


\section{DAFTAR PUSTAKA}

1. Ahdiyana, M. 2009. Dimensi OCB dalam Kinerja Organisasi.Yogyakarta: FISE UNY.

2. Arisman. 2013. Mengukur Kepuasan Masyarakat dan Kualitas Pelayanan Publik, Artikel Kemenkumham (Online), (www.google.com ), diakses 2 April 2016.

3. Badruzaman, Jajang. Pengaruh Budaya Organisasi dan Organizational Citizenship Behaviour (OCB) Terhadap Kualitas Layanan (Studi Kasus Pada RDUD Kota Tasikmalaya). Jurnal Akuntansi, Vol 7, No.1, Januari-Juni 2012. 66-91.

4. Bushra, Fatima, Usman, A., Naveed, A. 2011. Effect of Transformational Leadership on Employee's Job Satisfaction and Organizational Commitment in Banking Sector of Lahore Pakistan. International Journal of Business and Social Science. Volume 2, No.18, pp. 261-267.

5. Darto, M. 2014. Peran Organizational Citizenship Behaviour (OCB) dalam Peningkatan Kinerja Individu di Sektor Publik: sebuah analisa teoretis dan empiris, Jurnal Borneo Administrator,Vol.1, No.10, 10-33, (Online), (www.google.com ), diakses 12 Maret 2016.

6. Gardner, D.G \& Deadrick, D.L. 2008. Underprediction of Performance for US Minorities Using Cognitive Ability Measures. Equals Opportunities International. Vol 27, 455464.

7. Meilina, Restin. 2016. Pengaruh Karakteristik Pekerjaan, Kepuasan Kerja, dan Komitmen Organisasi Terhadap Organizational Citizenship Behaviour (OCB) Karyawan BRI Kediri. Jurnal Riset Ekonomi dan Bisnis (online) Vol.10, No.1, 61-72, tersedia http://ejournal.stiedewantara.ac.id ), diakses 1 Juli 2017.

8. Meilina, Restin. 2017. Optimalisasi Organizational Citizenship Behaviour (OCB) Untuk Meningkatkan Kualitas Pelayanan Publik di Kota Kediri. Makalah disajikan dalam Seminar Nasional Riset Manajemen dan Bisnis, Universitas Muhamadiyah Surakarta, Surakarta: 24 Mei 2017.

9. Puspitawati, Ni Made Dwi. 2013, Kepuasan Kerja dan Komitmen Organisasional: Pengaruhnya Terhadap Kualitas Layanan Hotel Bali Hyatt Sanur, Tesis (Online).Tersedia (www.unud.ac.id). Denpasar: Universitas Udayana.

10. Rudyanto, Ricky. 2012. Pengaruh Organizational Citizenship Behaviour (OCB) Pada Kualitas Layanan, Kepuasan Pelayanan, dan Kinerja (Studi pada Karyawan dan Pasien Rumah Sakit Islam Kustati Surakarta). Skripsi Universitas Sebelas Maret Surakarta, Surakarta (Online). (digilib@uns.ac.id), diakses 7 April 2016.

11. Sopiah. 2008. Perilaku Organisasi. Yogyakarta: Andi

12. Sugiyono. 2015. Metode Penelitian Kuantitatif, Kualitatif, $R \& D$. Bandung: Alfabeta.

13. Surachmad. 2010. Pengaruh Organizational Citizenship Behaviour (OCB) Terhadap Service Quality dan Dampaknya Pada Kepercayaan Pelanggan di PT Millenium Penata Futures Surabaya. Skripsi
Universitas Pembangunan Nasional (UPN) Veteran, Surabaya

14. Tranggono \& Kartika. 2008. Pengaruh Komitmen Organisasional dan Profesional Terhadap Kepuasan Kerja Auditor dengan Motivasi Sebagai Variabel Intervening, (Online). Jurnal Bisnis dan Ekonomi (JBE) Vol. 15, No.1. (www.google.com ), diakses 10 September 2014.

15. Undang-Undang Republik Indonesia No. 5 tahun 2014 Tentang Aparatur Sipil Negara. Kementrian Agraria dan Tata Ruang Badan Pertanahan Nasional (online). Tersedia (www.bpn.go.id ) diakses 20 juli 2017.

16. Wirawan. 2013. Kepemimpinan :Teori, Psikologi, Perilaku Organisasi, Aplikasi dan Penelitian . Jakarta : RajaGrafindo Persada. 